\title{
THE IDEOLOGICAL EFFECTS OF ACTUARIAL PRACTICES
}

\author{
JONATHAN SIMON
}

\begin{abstract}
Over the last century there has been significant growth within our society of practices that distribute costs and benefits to individuals based on statistical knowledge about the population. These actuarial practices like insurance premium setting and standardized testing in educational admissions are successful largely because they allow power to be exercised more effectively and at lower political cost. At the same time they generate ideological effects which have the potential to transform the way individuals understand themselves and their groups. In a 1977 case, Los Angeles Water and Power v. Manhart (435 U.S. 702), the United States Supreme Court considered a challenge to the actuarial use of gender in setting employee benefits. The case and the debates it generated illuminate the danger posed by the ideological effects of actuarial practices to our political culture in general, and to traditionally disempowered classes such as women in particular. At the same time it illustrates the limitation of traditional legal rights discourse as a means of resisting these dangers.
\end{abstract}

\section{INTRODUCTION}

Standardized testers ask us to blacken dots, insurance agents ask for our zip codes and marital status, and pollsters inquire as to which magazines we read and how many children we have. At the heart of these circuits of testing and questioning, comparing and ranking, are techniques that use statistics to represent the distribution of variables in a population. I refer to these techniques as actuarial, and the practices that rely on them as actuarial practices. These practices are so familiar and banal that it is difficult to notice them at all, let alone see them as central components of a new regime of social ordering linked to myriad exercises of social control and power, e.g., hiring, admitting, campaigning, selling, sentencing, and educating. Yet these practices are generating fundamental changes in our political culture.

I wish to thank the members of the Amherst Seminar on Legal Ideology and Legal Process for their helpful substantive and editorial comments on my paper. Patricia Ewick and Susan Silbey were particularly instrumental in drawing some coherence out of my original draft. The ideas presented here have been developed through conversations with many friends and teachers including: Marianne Constable, Francois Ewald, Sheldon Messinger, Robert Post, Paul Rabinow, and Kim Schepple. I owe a special debt to Susan Lehman who forced me to refine my ideas and contributed some of her own.

LAW \& SOCIETY REVIEW, Volume 22, Number 4 (1988) 
Through the lens of representations thrown off by these practices, individuals, once understood as moral or rational actors, are increasingly understood as locations in actuarial tables of variations. This shift from moral agent to actuarial subject marks a change in the way power is exercised on individuals by the state and other large organizations. Where power once sought to manipulate the choices of rational actors, it now seeks to predict behavior and situate subjects according to the risk they pose. The effects can be discerned on the way we understand ourselves, our communities, and our capacity for moral judgment and political action.

One's first response might be to point out that actuarial techniques are forms of knowledge gathering; the actions that are taken on the basis of this knowledge should not be blamed on knowledge. But actuarial practices cannot be dismissed as merely forms of knowing, when to be known is to be subjected to significant alterations in life opportunities. The relationship between knowledge and power is interactive. The statistical processing of information allows the exercise of power to be targeted quite precisely. Experts in marketing products and managing populations constantly give rise to new categories of people such as BUPies (black urban professionals), DINKS (double income no kids), high rate offenders, CHINS (children in need of service), and LDs (learning disabled children). Placing people in an actuarially defined category helps mark them as a new subpopulation that calls, in time, for new forms of testing, comparing, and ranking. Thus, school children may be placed in a particular track on the basis of standardized testing, but the track itself becomes a subject for further testing, comparison, and ranking.

Actuarial techniques play a central role in a proliferating set of social practices. They are at the same time a regime of truth, a way of exercising power, and a method of ordering social life. Actuarial practices have not seemed very important nor attracted much interest from social observers in part because they are already so familiar, and in part because they fit so unobtrusively into various substantive projects (e.g., educating, hiring, premium setting) in which they are subordinated as a means to an end. ${ }^{1}$ Yet this unobtrusiveness is precisely why they have become so important; they make power more effective and efficient by diminishing its political and moral fallout.

Similarly, Foucault ascribed the rise of disciplinary practices in the nineteenth century to their success in making the exercise

1 It is the particular usefulness of genealogical research as done by Nietsche and Foucault, that it seeks to analyze the political history of means (social technologies) as against the more familiar history of social ends. This can lead, however, to the illusion that techniques somehow transmit themselves apart from the strategic interest of subjects. Yet more traditional historiography suffers from the opposite malady of ignoring the way in which means endure beyond the ends for which they were deployed and often shape new situations within which strategic action takes place. 
of power less expensive and less politically volatile (1977). ${ }^{2}$ The disciplines were composed of techniques of surveillance and training that combined a detailed knowledge of the individual with methods of organizing minute individual actions. The disciplines replaced techniques of violence and intimidation that were both less precise and more troublesome in the political resistances they generated. I believe a genealogical analysis of the technologies through which power is exercised today would demonstrate that over the past half century we have been moving away from the disciplines and toward actuarial practices that are, in turn, more efficient in the use of resources and less dangerous in the political resistances they generate.

Disciplinary practices focus on the distribution of a behavior within a limited population (a factory workforce, prison inmates, school children, etc.). This distribution is around a norm, and power operates with the goal of closing the gap, narrowing the deviation, and moving subjects toward uniformity (workers are to be made more efficient and reliable, prisoners more docile, school children more attentive and respectful). Actuarial practices seek instead to map out the distribution and arrange strategies to maximize the efficiency of the population as it stands. Rather than seeking to change people ("normalize them," in Foucault's apt phrase), an actuarial regime seeks to manage them in place.

Thus, the actuarial regime uses the distribution of behavior (usually in a population much less spacially or institutionally defined) to construct circumstances that accommodate variations but nonetheless alter the consequences in the aggregate (for example, a risk pool in insurance). While the disciplinary regime attempts to alter individual behavior and motivation, the actuarial regime alters the physical and social structures within which individuals behave. The movement from normalization (closing the gap between distribution and norm) to accommodation (responding to variations in distributions) increases the efficiency of power because changing people is difficult and expensive. Actuarial practices are emerging as a dominant force because they further intensify the effectiveness of power set into motion by the rise of the disciplines.

It is not, however, simply a question of better technology. The emergence of actuarial practices also marks change in the social environment in which power must be exercised. As Foucault and Marx described them the disciplines were defensive strategies. They sought to fix and neutralize the mobile and dangerous elements of a population made uneasy through the breakdown of traditional communities during the early phase of capitalism. The

2 Foucault's study (1977) aroused new interest in the subject of the disciplines but this was not a new topic. Marx (1970), Weber (1948a), and Durkheim (1961) had already recognized the essential role of disciplinary practices in modern society. 
effort of the disciplines to control the bodies of individual subjects responded to the potential subversive power of those bodies when they were allowed to operate in disordered swarms. The revolutionary actions of the late eighteenth and early nineteenth centuries in which regimes were threatened by barricades and street crowds were an essential background to the insertion of disciplinary practices in prisons, asylums, and factory spaces (Foucault, 1977; Rothman, 1971). The disciplines sought to alleviate this threat by directly organizing the bodies and spaces of the "dangerous classes" (Chevalier, 1958).

Beginning in the late nineteenth century new strategies of social control using actuarial techniques began to develop that operated on populations rather than bodies. Social insurance, worker's compensation, income tax, and similar devices created forms of management that did not need to rely on the cumbersome techniques of individual discipline (Ewald, 1986). The present regime of power that tests, compares, and situates us, while withdrawing from a direct coercion of our bodies and pleasures, allows deviation (gaps from the norm) to survive because it can afford to do so. The shift toward actuarial practices evidences the growth in the stability and confidence of power. In part this is a testament to the effectiveness of the disciplines in producing a population that is more docile and manageable. At the same time, it corresponds to changes in economic life that make the mobilization of labor power less intensive than it is in a growing industrial society. In our present social circumstances, it is cheaper to know and plan around peoples' failings than to normalize them. ${ }^{3}$

In addition to these instrumental consequences, the shift toward actuarial practices alters the way we understand our status as subjects, both individual and group. By placing people in groups that have no experienced meaning for the members, and therefore lack the capacity to realize common goals or purposes, actuarial methods imply a particular view of individuals and their communities. ${ }^{4}$ As people come to understand themselves through these actuarial representations they may be stripped of a certain quality of belongingness to others that has long played a role in our culture.

3 Nietzche writes in the second essay of his On the Genealogy of Morals (1967):

It is possible to imagine a society flushed with such a sense of power that it could afford to let its offenders go unpunished. What greater luxury is there for a society to indulge in? "Why should I bother about those parasites of mine?" such a society might ask. "Let them take all they want. I have plenty."

Ironically the penal system seems to be one of the areas where we cling most tightly to a disciplinary vision of exercising power.

4 The distinction I am trying to draw between association based on experienced meaning and that assigned by abstract processes such as statistics shares some features with Habermas' distinction between interactive and technical relations (Habermas, 1971), or more recently, his analysis of lifeworld and system (1987). 
Because actuarial practices have the capacity to affect how we organize ourselves and our sense of belonging to others, they have ideological meaning. By ideological I do not mean false representations that are used to control an otherwise autonomous subject. Rather, I refer to the way our social practices reflect ourselves to ourselves. It is through the network of significance offered to us by our practical involvements that we arrive at our subjectness (Heidegger, 1962; Gramsci, 1971; Althusser, 1971). This network will, of course, reflect the structure of power that operates through practical involvements.

The success of actuarial methods in shaping a new ideological basis for the governance of social life will be marked by its ability to colonize legal discourse with its representations. Law is one of the primary ways in which a sustained effort is made to rationalize choices about which solutions should be employed to manage social problems. Laws do this by subjecting social practices to an inquisition that demands the manner of representation be justified and generalized. Legal discourse spreads and reinforces the logic of those representations that it affirms (of course it can also work on occasion to delegitimize and dissolve representations).

In America, because of the central role of law in maintaining ideological structures, struggles over the imposition of actuarial practices are often fought out on a legal terrain. There have been local resistances to actuarial practices, although we rarely understand them as belonging to a critical struggle over who we are. In 1978 the Supreme Court decided a case that involved resistance to actuarial practices. City of Los Angeles Department of Water and Power v. Manhart (435 U.S. 702 (1978)) involved a challenge under Title VII of the Civil Rights Act of 1964 to the retirement benefit system of the Los Angeles Department of Water and Power. The plaintiffs charged that the practice of requiring a higher contribution to the retirement plan from female employees, based on the longer expected lifespan of females, violated Title VII's prohibition on discrimination on the basis of sex in employment compensation. Manhart provides an opportunity to view the clash between actuarial practices and the value our culture has traditionally placed on the sovereign individual.

In this essay I want to take the Manhart decision, and the attendant critical discourse out of the context of gender discrimination and read it as a text about the ideological difficulties created by these new techniques of power. First, I will closely examine the majority opinion and some of the critical response that appeared in law review articles following the case. Second, I will explore the limitations of these legal discourses in coming to terms with the ideological effects of actuarial practices. Finally, I will offer a reinterpretation of what is at stake in the proliferation of these practices and suggest how a different approach to antidis- 
crimination law might provide a better tool for resistance than the currently dominant rights jurisprudence.

\section{ACTUARIAL PRACTICES AND LEGAL DISCOURSE: LOS ANGELES DEPARTMENT OF WATER AND POWER V. MANHART}

The proliferation of actuarial practices within our society has not taken place without resistance. ${ }^{5}$ While they provide a highly efficient means of management, actuarial practices also conflict with other powerful traditions in our cultural background. Because they operate on the basis of aggregate data, they conflict with the strongly held value that people be considered primarily as individuals. Because they operate in terms of predicted future outcomes, they conflict with the related value that those aspects of a person that reflect her intentional efforts be privileged over those aspects that are involuntary. Finally, because they demoralizetreat as morally neutral-differences that carry highly-charged political and social significance (such as race and gender), they threaten to obscure the historical effects of domination and conflict with modern efforts to remedy discrimination. ${ }^{6}$

Law plays a central role in our political culture as the place wherein the rationality of social practices can be discussed, and thus it is not unexpected that resistance to actuarial practices has found its way into legal discourse. Value conflicts are entailed in the production of social policy whether it concerns the placement of a highway or a mechanism for military conscription. These choices are challenged, tested, and legitimized in the discourse produced by courts and lawyers (Brigham, 1987). Yet our legal discourse is itself a medium structured by historical practices and ideologies. Certain effects of social practices will be seen as important, while others remain obscure. As a result it shapes in advance the way in which the policy debate can be articulated (Unger, 1975).

With respect to actuarial practices, the first two forms of conflict, that express the importance of individual autonomy, are easily expressed within the usual categories of legal understanding. The third conflict, which concerns the political meaning of social

5 Insurance pricing has set off a number of political struggles, especially against the practice of redlining, i.e., excluding entire neighborhoods from insurance or consumer credit because of poverty and race. These struggles have generated various legislative measures (cf. Austin, 1983). More recently AIDS has led some insurers to seek the exclusion of people they suspect of belonging to high risk groups. This has been strongly resisted and in some states such as California has led to legislation forbidding AIDS testing for insurance purposes.

6 The sense of repulsion we feel in being treated actuarially (for example, buying auto insurance or applying to law school) is anything but trivial. It represents the call of something still very much alive in our sense of self (both individual and collective) that is profoundly threatened by these practices. 
categories and their relevance for discrimination, is far more difficult to fit into a legal dispute. While it is undeniable that law has grown through the pressure of social movements, the political reality of these movements is generally covered up by these same laws. The tendency of legal discourse is to express the hard won gains of social movements as a priori universal rights-previously existing, newly articulated or discovered rights-that have no connection to the contingencies of historical struggle and change. In addition, these rights are granted to individuals rather than groups. Those examples of legal opinions that have come close to acknowledging the social and political basis of law have been denounced for precisely that reason. ${ }^{7}$

The exclusion of this third dilemma from the legal debate over actuarial practices forces us into a choice between individual and group models of equity. This choice necessarily suppresses what is most invidious about actuarial practices, i.e., the ideological effects it has on group identity.

The leading case to consider actuarial practices arose in the context of gender discrimination. In City of Los Angeles Department of Power and Water v. Manhart (435 U.S. 702 (1978)), the Supreme Court struck down the use of gender as an actuarial variable in establishing the amount of employee contribution to a retirement benefit plan as a violation of Title VII of the Civil Rights Act of $1964 .^{8}$ I want to examine the discourse of the Manhart decision and the intense debate that arose in several law reviews concerning the propriety of the decision to illustrate tensions arising in our culture from the expansion of actuarial practices. ${ }^{9}$ At the same time these discourses illustrate the limitations placed on resistance by the prevailing structure of legal rationality.

The benefit plan provided by Los Angeles Department of Water and Power required higher contributions from female employees because statistically they live longer than men. Since it disadvantaged women on its face, the plan seemed to violate Title VII's proscription against discrimination in the terms or conditions of employment on the basis of sex. As individuals, women were disadvantaged by paying higher contributions to the plan while

7 Brown v. Board of Education, 347 U.S. 483 (1954) acknowledged that historical changes in race relations and in the social role of education were significant reasons for rejecting precedent and finding segregated education unconstitutional. This aspect of the opinion was attacked in a line of argument initiated by Herbert Wechsler's article entitled, "Toward Neutral Principles of Constitutional Law," 73 Harvard Law Review 1 (1959).

8 The Civil Rights Act of 1964, Title VII provides in part that:

It shall be an unlawful employment practice for an employer to fail to hire or to discharge any individual, or otherwise to discriminate against any individual with respect to his compensation, terms, conditions, or privileges of employment, because of such individual's race, color, religion, sex or national origin . . .

9 See Kimball (1979); Brilmayer et al. (1980); Kimball (1980); Laycock and Sullivan (1981); Benston (1982); Brilmayer et al. (1983); Benston (1983). 
having no certainty that they would live the additional years required to reach parity. As an aggregate group, however, female employees could expect to receive the same benefits as male employees. Indeed if, statistically, men die at a younger age than women, a plan requiring equal contributions and providing equal payouts will tend to favor women. Because the Court took the gender gap in longevity to be statistically accurate, its determination of whether or not Los Angeles Water and Power discriminated rested on the question of whether Title VII is really aimed at groups or at individuals.

Furthermore, the facts in Manhart posed a distinction that seemed without any discriminatory prejudice or stereotyping of women. Justice Stevens's majority opinion assumed that longevity-correctly or incorrectly asserted-is morally neutral, i.e., it is unlikely to stigmatize those to which it is attributed. Since Manhart posed a classification that did not incorporate a disfavored social attribute (no one argues that longevity is bad), it strained the traditional justifications for antidiscrimination law.

Stereotyping, or the imposition of assumptions about a group on an individual, has been central to antidiscrimination law because of the prominence of individual autonomy as a juridical value. Manhart stretches this conception in order to fit actuarial representation into the mold of devaluing moral attributions (blacks are violent, Mexicans are lazy, Jews are cheap, women live longer). This strain, however, allows Manhart to articulate the nascent cultural resistance we have to actuarial practices in the traditional values of individual autonomy.

On the surface the opinion in Manhart has no problem accommodating traditional values. Justice Stevens argued that the use of gender is unlawful where it negatively affects an individual for whom the classification is inaccurate. Stevens argues that the individual, rather than the group, is the appropriate subject of antidiscrimination law (Manhart, 435 U.S. at 708):

The question ... is whether the existence or nonexistence of "discrimination" is to be determined by comparison of class characteristics or individual characteristics. . . The statute's focus on the individual is unambiguous. It precludes treatment of individuals as simply components of a racial, religious, sexual, or national class. . . . Even a true generalization about the class is an insufficient reason for disqualifying an individual to whom the generalization does not apply.

Despite his acknowledgement that the actuarial classification of women in terms of longevity differs from traditional prejudiced classifications, Stevens manages to fit the case back into the traditional analysis of stereotypes. "Practices that classify employees in terms of religion, race, or sex, tend to preserve traditional assumptions about groups rather than thoughtful scrutiny of individuals" 
(Manhart, 435 U.S. at 709). By focusing the legal analysis on whether the statute is concerned with groups or individuals Stevens's opinion covers up the ideological effects of the actuarial practices at issue in Manhart.

Stevens's reading of Title VII, however, creates a number of problems. First, it contradicts cases in which the Court has allowed a Title VII violation to rest on a showing of group disparity without evidence of a specific intent to discriminate against individual members of that group (Griggs v. Duke Power Co., 401 U.S. 424 (1971)). ${ }^{10}$ As Justice Powell has pointed out, insistence on a rigid individualism concerning the aim of Title VII renders this important "disparate impact" line of cases incoherent (Connecticut v. Teal, 457 U.S. 440 (1982), 458-459, Powell, J., dissenting)). If Title VII is exclusively aimed at protecting the individual it is difficult to see how a showing of disadvantaging on the aggregate should have any bearing.

Second, Stevens's focus on the individual would seem to bar remedial solutions that redress historical discrimination against groups at the cost of treating individuals on the basis of their group membership. Affirmative action plans justified on the basis of past discrimination against a group would seem to violate Title VII if they result in the disadvantaging of individuals on the basis of their race, or other proscribed difference. Yet the Court upheld just such a scheme in United Steel Workers v. Weber (443 U.S. 193 (1979)).

Manhart gave rise to a storm of controversy. One group of writers, whom I shall refer to as insurance-oriented critics, attacked the decision as destructive of the rational calculation of risk on which "fair" insurance is based. More strongly, they expressed a kind of shock that what appeared in their paradigm as a valuefree technical decision (to use gender in setting benefit premiums) had been adjudged as discrimination. A second group of writers, whom I call rights-oriented critics, defended the decision as a logical extension of the field of antidiscrimination law. These writers celebrated the decision as a sign of the Court's willingness to look beyond the authority claims of a technical elite to root out biased treatment of women.

10 In Griggs v. Duke Power Co., 401 U.S. 424 (1971), the Court held that a prima facie case of discrimination under the Civil Rights Act of 1964, Title VII could be made out showing that a particular practice disadvantaged as an aggregate a class of people protected by Title VII. In that case, the company required applicants for certain higher job categories to have a high school education and a certain score on a standardized aptitude test. The district court found that this negatively impacted blacks as a class. The Supreme Court held that such a showing made out a prima facie case for violation of Title VII and placed the burden on the employer to show that the requirements were directly related to work involved. 


\section{A. The Insurance-Oriented Critique of Manhart}

For insurance-oriented thinkers, the Manhart decision is more than wrongly decided, it is an assault on what they conceive of as scientifically established reality. From their point of view, a neutral, indeed beneficent, process of social policy has been unfairly linked to the brutish tradition of racism and sexism. Justice Stevens's opinion, from this perspective, is an attempt to impose political power over truth (Kimball, 1979: 96):

It is quite beyond the capacity of Congress to command reality to correspond to its mandates. Within limits Congress may order employers (or even insurers) to ignore reality and to act in accordance with the fiction that men and women do not differ. ... [T] [Te question then is whether the statute [Title VII] commands us to ignore that reality.

The insurance-oriented critics deny there is any differential treatment of individual women. From their perspective, actuarial methods represent people in terms of risk, that is, in terms of the contingent future. The object being exchanged in annuity plans is not money at all, but assurance against a frightening uncertaintyliving beyond one's savings, i.e., poverty in old age. Thus the fact that women pay more in contributions, or receive less per pay period after retirement is not a fair measure of what they receive. Because of differential longevity, the annuity plans provide an equal assurance of an equal economic position through old age.

Yet the very fact of the lawsuit in Manhart suggests that the employees do not share the formalized representation of themselves that is constructed by actuarial methods. Where the insurance-oriented critics see in gender only a distinction with a technical bearing on longevity, the plaintiffs saw the political and moral significance invested by a history of sexist domination. The blindness of actuarial vision to the political and moral meaning of certain differences is manifest in the response of the insurance-oriented critics to one of Justice Stevens's points. Stevens wrote (Manhart, 435 U.S. at 710, footnotes omitted):

Treating different classes of risks as though they were the same for purposes of group insurance is a common practice that has never been considered inherently unfair. To insure the flabby and the fit as though they were equivalent risks may be more common than treating men and women alike; but nothing more than habit makes one "subsidy" seem less fair than the other.

The insurance-oriented critics reject this analysis. They argue that since any subsidy would be unfair, the real question is what subsidies can be feasibly eliminated in the context of group insurance policies (Kimball, 1979: 107; Benston, 1982: 501-502).11 The

11 But Justice Stevens is not speaking of "fairness" within an actuarial logic. He is speaking of the sense of "fairness" in a culture that is still sensi- 
question of whether certain differences have a moral significance does not show up in their discourse.

What the insurance-oriented critics offer is an actuarial conception of "fair discrimination" that is stripped of the meanings left by the history of gender domination. Kimball (1979: 103) argues that, historically, discrimination meant simply the act of dividing, separating, and distinguishing. It took on a negative tone only when coupled with the cognate "against." The original meaning has been lost in an expanding field of antidiscrimination law. The insurance-oriented critics seek to revive the concept of "fair discrimination" (Kimball, 1979: 105):

"Fair" discrimination has never been illegal; it was and is not only permissible but also required as the essence of good ratemaking techniques in insurance; the goal of the ratemaking process is to discriminate fairly-to measure as accurately as is practicable the burden shifted to the insurance fund by the policy holder and to charge exactly for it, no more and no less. To do so is "fair" discrimination in the seventy year old tradition of insurance rate law and the much older practice of the insurance business. Not to do so is unfair discrimination.

On this basis, the insurance-oriented critics argue that there is no unfair discrimination against women involved in the benefit plan at issue in Manhart. Indeed on this account eliminating the differential would constitute unfair discrimination against men since they would be appraised under a scheme that was not as efficient as possible.

\section{B. The Legal-Rights-Oriented Defense of Manhart}

Brilmayer, Hekeler, Laycock, and Sullivan, responded to Kimball's article with a defense of the Manhart decision. Their defense is constructed self-consciously within the legal rights discourse (Brilmayer et al., 1980: 508):

The question, therefore, is whether in this context Title VII requires equality for individuals or equality for groups. One reason for the vigorous and so far unproductive disagreement about the answer may be that most of the antagonists come from fundamentally different intellectual traditions with respect to the individuals-versusgroups issue. The insurance tradition analyzes risks, premiums, and benefit schedules in terms of groups; most actuaries cannot think of individuals except as members of groups. As we shall show, however, the main civil rights tradition analyzes rights in terms of individuals. Its most fundamental principle has been that no individual shall be considered simply as part of a racial, sexual, religious, or

tive to historically invested meaning in particular distinctions including gender. 
ethnic group, or treated differently because of his membership in such a group.

As does Justice Stevens, the rights-oriented critics view the issue as one of treating individuals in terms of their group membership. But they go further by rejecting what Stevens assumed; they deny that the actuarial use of gender is either neutral or accurate. For the rights-oriented critics, the statistical association between longevity and gender ignores the point of antidiscrimination law. They contend that Kimball's "expectation argument"-that men and women paying different annuity premiums will receive equal assurance against poverty in old age-assumes what is in question, that gender can be used to calculate expectation in the first place.

This attack has two dimensions. First, the rights-oriented critics argue that any classification by gender in insurance benefits suffers from all the evils of classification that antidiscrimination law and the Civil Rights Act intended to eliminate. They summarize the underlying purposes of the act as follows (Brilmayer et al., 1980: 526-527):

Race, color, sex, religion, and national origin share three characteristics that justify the restrictions on their use. First, they are ascriptive and immutable. Second, they have been widely misused throughout history. Third, they are generally irrelevant to employment decisions.

Brilmayer emphasizes the strong resistance in our culture to allocating significant costs and benefits on the basis of immutable characteristics. Such distributions are faulty because they seem to reward and punish people for what they are not responsible for, and they create no incentive to make individual choices. Furthermore, immutable classifications make us suspicious of the presence of discriminatory intent. Immutability means that those who may be wielding the power to classify have no risk of being subjected to their own strictures. This suspicion is reinforced in their argument by the history of discrimination in the insurance business (Ibid., p. 529). Antidiscrimination law also reflects a strong cultural assumption that immutable characteristics, and other rather permanent ones like religion, are largely irrelevant for making social choices. The history of prejudice concerning certain differences such as race and gender (and the social disadvantaging that has gone along with prejudice) make us suspect that what appear to be effects of these differences are really effects of the disadvantages.

Whereas Stevens viewed Manhart as posing an extension of gender discrimination law beyond the settled questions of inaccurate stereotypes, Brilmayer and her co-authors view the case as a straightforward application of that law (1980: 510):

The association between sex and mortality is no different from any other association between forbidden and permissible criteria. American women as a group currently live 
longer than American men as a group, just as they are able to lift less weight as a group. But some women will die at a younger age than some men, just as some will be able to lift more weight.

The second direction of attack is against the technical accuracy of gender differential. The rights-oriented critics argue that gender is not the genuine "cause" of longevity differences. Other measurable factors exist that could adequately reflect longevity for insurance purposes, e.g., smoking and stress-related occupations. The rights-oriented critics suggest that the difference between men and women in longevity is an effect of the historic pattern of opportunities for each gender. Here, however, the advantaging of men has worked perversely to make them better candidates for heart attacks and other stress and smoking-related diseases (Brilmayer et al., 1980: 531-537).12

While both sides view causation as an empirical and technical question, their different valuations embody a normative difference. Implicit in the legal rights-oriented critics' concern for causality is the notion that things that happen to people should reflect some sense of desert, i.e., of the individual's responsibility for her own actions. If the fact that men die earlier reflects the fact that men engage in behavior that leads to their death, then a moral choice is being hidden by a statistical association.

The underlying moral dimension in the legal rights-oriented writers' concern with causation is clear from their response to the charge that men are unfairly treated by an equal contribution scheme (Brilmayer et al., 1983: 226):

It is hard to understand why the use of merged-gender mortality tables is unfair to men. It has a disparate impact on men as a group because it disadvantages self-destructors, and more men than women are self-destructors. The total annuity payout to . . .500 hypothetical men would be less than the total amount paid to the 500 women because the total number of years the men would live would be less. But are men, especially non-self-destructors, entitled to cash in on the fact that many of their sex self-destruct. . .

Presumably if some class of people should be disadvantaged by a group-based pension plan, it is "self-destructors," i.e., those whose individual choices and actions have led to this end. The in-

12 The insurance-oriented critics argue that cause per se is not important. Even if gender is a proxy for other factors it may be the most efficient proxy available for otherwise difficult to measure characteristics. Then the significant question is whether changing social patterns (e.g., more women smokers) will render actuarial tables used now to assess contributions incorrect by the time the employee cohort reaches retirement. Thus, Benston argues that causality is unlikely to detrimentally effect the actuarial scheme: "It is preferable that the postulated relationship be grounded in a theory that efficiently predicts the effect of changed circumstances on life expectancy. But this is not necessary if past relationships have been stable and previous predictions accurate." (1982: 514). 
surance-oriented critics simply do not confront within their discourse the question of whether one distribution of risk is normatively superior to another. The only real basis for distinction is the efficiency of distribution. If a causal theory provides for more efficient and reliable distribution it is superior, if not, it is irrelevant.

\section{RE-INTERPRETING THE DANGER OF ACTUARIAL PRACTICES}

\section{A. Critique of the Insurance and Rights Discourses}

Neither the insurance nor the rights discourse provides an adequate basis for understanding the social policy choices really at stake in Manhart. Both discourses provide points that resonate with important traditions within our cultural practices, but both do so at the cost of ignoring the force of the alternative tradition.

The insurance-oriented critics build their argument against Manhart around the concept of "fair discrimination." Inherent in the policy of measuring the "burden shifted by the policy holder," and "charg[ing] exactly for it" (Kimball, 1979: 105), is the notion that each person should be assessed precisely in terms of the burden of risk that she creates. Despite the appeal of this logic in a market society, there is, in fact, no way to know precisely what burden an individual will place on the insurance plan because individual longevity is not knowable in advance. In practice the strategy of internalizing costs involves choosing among various ways of distributing the full cost among a group of employees. One could imagine making blondes or right-handed people pay more, or one could decide that the relevant group to share the costs is the group of employees as a whole. All insurance schemes perform a function of risk spreading. Why should this spreading end with the gender distinction? If women cannot change anything to affect the burden they place on the pension scheme, and if, as individuals, they are in no way responsible for the differential and may not get to enjoy it, why should they absorb the cost?

The insurance-oriented critics defend themselves with microeconomic cost internalization theory. On this account it is more efficient to link price as accurately as possible to risk because it allows individuals to allocate their resources in a way that advances their interests. To go from all people, to groups distinguished by gender is, on this account, a step toward individualizing costs (Benston, 1982). A person likely to live a long time may find that the high cost of an annuity reflects her own perception that the risk of living beyond one's working years is quite high, and thus the need for a pension great (Lautzenheiser, 1982: 38, cited in Benston, 1982: 518):

If a person knows he or she has a higher probability of dying because of any of the elements-health, occupation, family history, avocation-would he or she not be unwise 
to buy an annuity which pays only for long life, not short life? In the case of an annuity, then, self selection is done by the insured (annuitant) in advance for all the elements except age and sex.

However, it is by no means obvious that this self-selection process takes place. (How many of us who smoke or drink or the like actually acknowledge that we will live a shorter life let alone make concrete economic choices based on that fact?) The insurance-oriented critics are vulnerable to the traditional counterthrust against price systems of allocation-that the potential for consumer choice is overestimated. The gender difference is not large or certain enough to affect the calculations of the average person as to whether paying for the risk to be distributed is worthwhile.

Nonetheless, the rights-oriented position is also suspect. Brilmayer and her co-authors accept Stevens's logic that Manhart raises the question whether Title VII protects individuals or groups and argue that it should be read to protect individuals. By emphasizing individualism, the rights-oriented critics blind themselves to the importance that aggregation through actuarial techniques plays in our social life. We live in a society where aggregations are increasingly important ways of exercising power; strategies of resistance must also be able to operate at the level of aggregates. By opting to enshrine the individual, the rights critics renounce remedial strategies such as affirmative action that rely on groups. ${ }^{13}$

In addition, the link these critics make between costs and responsibility for choosing courses of action ultimately ignores the dynamics of modern social practices and policies. Increasingly we live in a world where costs are discontinuous with responsibility. Highway accidents, air pollution, and economic dislocations, all have causes in some sense, but practically they are social problems that require social solutions. Indeed, it is the rising recognition of the social bases of harms that has fueled the growth of actuarial technologies as ways of socially managing risk (Ewald, 1986; Simon, 1987).

It would be a mistake, however, to view the individualism of rights discourse as the only reason it falters in the effort to grasp the ideological effects of actuarial practices. The critique of liberal rights jurisprudence produced by the Critical Legal Studies movement provides a basis for analyzing the legal struggle around actuarial practices that avoids the errors of rights discourse, but that also fails to grasp the ideological threat.

In a penetrating analysis of insurance classification controversies, Regina Austin (1983) seeks to reintroduce the political dimension of actuarial practices excluded by liberal rights jurisprudence.

13 They would limit affirmative action to a narrow range of situations under Title VII (Brilmayer et al., 1980: 525 n.95). 
She argues that classification generates conflict because it represents and reinforces the current hierarchical ordering of status groups in modern society through which both individuals and groups are disadvantaged. The individual who seeks to move upward in a stratified society is impeded by the prevalence of insurance systems that impose costs on her on the basis of her existing status group. The social group that shares bonds of internal solidarity is also hindered by classification procedures that strip their communities of economic resources by excluding them from the provision of insurance.

Austin suggests that litigation concerning classification has the promise of being nascent form of class conflict. But the struggle breaking out around insurance classification is rendered ineffective by the hegemony of liberal modes of criticism. Liberal criticism channels discontent in the directions of personal autonomy, or interest group pluralism (1983: 580). The two appear to differ, but in fact share a basic acceptance of the status quo distribution of power and opportunity in society. In the insurance context resistance is channeled toward either the unfairness of treating the individual on the basis of group experiences, or toward bargaining for a better position for one's group. Austin offers an alternative to these liberal strategies embodied in the rights critics' position; she urges the formation of real "voluntary groups or communities whose members are engaged in economic and social tasks relevant to the control of risks and the provision of support and resources for victims of accidents and losses" (1983: 581). In effect, she is arguing that risk decisions be democratized. This democraticization requires the formation of sovereign communities capable of exercising political power.

My analysis, however, suggests that the ideological effects of actuarial practices, render more difficult the formation of precisely the sort of communities Austin describes. While Austin suggests that insurance classification practices reinforce status hierarchies, I argue that they do so at the cost of undermining the forms of shared significance that define a status group. Insurance, and other actuarial practices, reinforce hierarchy; but they also transform the hierarchy into one of aggregates rather than status groups.

Austin recognizes this position when she says that actuarial representations fragment the individual, but she fails to acknowledge its significance for immobilizing social groups (1983: 547):

Insurance companies do not view any insured as a whole person. Rather, every insured is compartmentalized. $\mathrm{He}$ is the sum of the many roles he plays as a result of being a member of many status groups. To an insurance company, the same individual may be an adult, a female, a divorcee, a parent, a lover, an executive, a debtor, a homeowner, a citizen, an urbanite, a commuter, a teetotaler, a 
lawbreaker, and a klutz. She is not a plenary, monolithic person. The company does not know her; it knows only the roles she plays. ... A Although the multiplicity of roles may cause the individual to suffer normative conflict and uncertainty, role or status inconsistency does not impede insurers.

It is true that we live a multiplicity of roles, some of which constitute status groups in the Weberian sense. But we also think of ourselves as plenary. Although this may be an illusion, it is an illusion sustained by the power of some group identities to give us a way of interpreting our other roles. Actuarial representations undercut this self-interpreting capacity. Austin's conception of a just solution to insurance controversy envisions the transformation of the present status group hierarchy toward egalitarian communities that combine internal solidarity with democratic political organs. Yet the effect of actuarial practices is precisely to make it more difficult for groups to intensify their solidarity or to exercise political choice. As Austin herself points out, ". . . insurance cells are artificial; they do not necessarily relate to real collectivities or groups with which the cell occupants identity and in which they participate." (1983: 547).

I want to argue that the representations produced by actuarial practices, e.g., insurance cells, place us in a cultural space even more alienating and disempowering than the disciplinary bureaucratic practices we have occupied for most of the last century. The theoretical work of the Critical Legal Studies movement, which Austin draws on, seems to miss the significance of the increasingly visible shift in society from status and class groups to aggregations (Unger, 1975; Frug, 1980; Kennedy, 1976). To these scholars, the major ideological foe is liberalism, and the most important practices are bureaucracy and capitalism. While these forces remain central to understanding our society, they are being altered by the proliferation of actuarial practices and the ideological effects of those practices.

\section{B. The Cultural Logic of Actuarial Practices: Making and Unmaking People}

The rights- and insurance-oriented discourses provide interpretive nets that seek to make sense of our social world; they incorporate the most powerful languages within which we find ourselves debating public policy. One can think of other discourses, religion or revolutionary rhetoric, for example, but these, for a variety of reasons, have been less powerful in contemporary political life. Nonetheless, neither rights or insurance talk seems to provide an interpretive net that adequately accounts for the diversity that exists within our present social practices or our contemporary 
notions about fairness. ${ }^{14}$ I maintain that one must observe the ways actuarial practices contribute to the construction of social groups and persons to be able to appreciate and possibly imagine our way beyond the limitations of these two discourses. The proper place to begin is with our own sense of unease at how we are represented in actuarial practices.

The predominant understanding of political action in our culture founds it in the sovereignty of the individual subject or in attributing sovereign subjecthood to groups. Laws often treat groups as if they were individual subjects capable of intentions, decisions, and failings. This reflects certain historical and political agendas (e.g., the protection of investors through the fiction of the corporation) but it also denotes a set of sociological conditions. The subjecthood of groups has depended on the ability to include and exclude people, sanction or reward them, mobilize or diffuse them. These faculties are composed at the micro-level by shared discourses, common means of understanding the situation, and the ability to limit access to knowledge of what the group is doing. Through these sorts of material features, groups are able to ascertain sentiments, shape a controlling interpretation of the situation, mobilize members for action, and deliver power. However, actuarial practices make it more and more difficult for group subjecthood to develop (or reproduce itself) by undermining these capacities.

In the nineteenth and early twentieth centuries scholars focused on the shift in group character from status groups to collectivities defined by their contractual position (classes). The former are held together by internal bonds, while the latter tend to be defined by external pressures. ${ }^{15}$ While classes can develop internal

14 Rights-oriented discourse derives from the centuries long traditions of common law, and western political theory, while the insurance/economic-oriented discourse stems from the tradition of the social sciences. It is unlikely that there is a logically derivative meta-language that would enable us to move from one to the other. Nor is it likely that we can fashion a new, more comprehensive discourse out of thin air. Discourses are assembled, over time, from elements that linger throughout culture. Far from being mere "carriers" of self-generating discursive genotypes, humans are the skillful mechanics of this ideological machinery. We work from the junk pile that history has left us. We can never be sure if the machine we build will accomplish the ends we have dreamt of, or what else it may accomplish. This does not mean, however, an end to the useiulness of rational reflection on human practices. But it does argue for the usefulness of interpretive methods that seek to illuminate elements that underlie the ways we talk and think about social problems. Working from the product of such interpretation, it is possible to suggest new combinations of elements. What results may be of only local usefulness within one region of social life, or it may not be useful at all. Over time such local improvisation can lead to a broader framework.

15 Weber defines a status group as internally mobilized:

... a plurality of persons who, within a larger group, successfully claim a special social esteem ... [they] may come into being; in the first instance, by virtue of their own style of life, particularly the type of vocation ... [In] the second instance, through hereditary charisma, by virtue of successful claims to higher-ranking descent; hereditary 
bonds through the pressure of external forces (class consciousness) the rise of class as a predominant form of identity in a society permanently diminishes the intensity of internal bonds. It is possible to think of aggregates as a third kind of collectivity, one defined neither by internal bonds, nor external experiences, but by locations on a statistical distribution.

The kind of groups whose formation is encouraged by actuarial practices are aggregates; conglomerations of people whose belonging together is unrelated to any significant traditions, discourses, or action. Actuarial practices define as groups assemblies of people which are singularly sterile in their capacity for political empowerment. Where they locate divisions along dimensions of traditionally recognized difference (e.g., gender) actuarial practices tend to separate this difference from the political and moral significance that history has built up.

Aggregations are familiar in law in the form of class action lawsuits. While a legal class may consist of status, classes, or interest groups, they commonly are made up of people with only a formal attribute in common, e.g., all of those people who bought or sold shares of a stock that was being manipulated by inside trading. Legal scholars have recognized the serious problems that arise for the normal theory of legal representation by the absence of any real solidarity or even objective interest on the part of class members (Rhode, 1982). Bereft of shared traditions, discourses, or of any real mechanism for exercising political power, legal classes become the puppet of whomever is capable of manipulating the flow of information, usually the lawyers. Just as the class action threatens to outstrip the concept of a legal subject and renders representation problematic, the rising importance of aggregates in contemporary political life threatens our democratic traditions. ${ }^{16}$

People understand themselves along the divisions that power invests with significance. The more a particular dimension of socially recognized difference marks an actual difference in life opportunities, the more powerfully does that dimension stand out as a mark of identity and belonging. That is why, paradoxically, the most intensely discriminated groups often develop the most powerful sense of group identity, e.g., the Jews and American blacks. ${ }^{17}$

status groups, or through monopolistic appropriation of political or hierocratic groups; political or hierocratic status groups. (Weber, 1968: 306).

16 The burden of my argument is that these are intertwined with the parallel rise of actuarial practices. By representing people in a certain way, as members of aggregates defined by formal attributes, actuarial practices make it possible for power to target individuals in terms of their location within a population. Whatever instrumental effects this has, it also has ideological effects. It calls us forth as a specific kind of subject (cf. Louis Althusser 1971).

17 The substance and intensity of the identity produced for specific dimensions of difference can be expected to vary tremendously. The play of domination across differences creates very distinct sorts of group identities. For example, while racism and sexism are both forms of domination through 
Actuarial practices, however, construct groups along dimensions that erode the basis of collective identity and action.

It is important to recognize that this disempowering effect does not arise simply from the practice of classifying. Power has been exercised over people through techniques of classification for a long time now; actuarial practices produce a very particular kind of classification. Hacking has studied the way that western societies since the beginning of the nineteenth century have been increasingly obsessed with classifying the population, and identifying people as types requiring more or less social control (1986: 223-224). These classification and counting practices have resulted in what Hacking calls "making up" subjects underlying the perceived conduct of individuals. In this way homosexuals, the mentally ill, and delinquents have been "constructed" since the beginning of the nineteenth century. ${ }^{18}$ These constructed identities were the effects of specific exercises of power and knowledge, and they came to constitute a target for further exercises of power as the mentally ill were concentrated in asylums, delinquents in prisons, and homosexuals in both.

Contemporary society goes on about the business of exercising power on people based on classifications. But the sort of classifications developed by modern actuarial technologies are different. They lack the subjectivity underlying the categories of earlier classification practices. That is, as forms of knowledge they do not assume any particular subject; as strategies of power they do not target subjects.

Consider an example from the genealogy of delinquency. Criminal policy has always been especially concerned with people who commit many crimes, but there is an important shift between the habitual offender (a ghost from the classification machine that has haunted criminal justice policy since the nineteenth century) and the latest target of criminological research, the high-rate offender. The former classification focused on a presumed underlying quality of the individual subject. Thus sociologist Ernest Burgess, writing in the 1920 s, says this about the habitual offender (Bruce, Harns, Burgess, Landesco, 1968: 210):

The so-called habitual criminal type includes [such] other groups besides [the] alcoholic, as the drug addict, the gambler, the tramp, the ne'er do well. Individuals in these groups require far more careful and specialized treatment both within the penal and reformatory institutions and outside under supervision than do the first and occasional

difference, the underlying subjects constituted have been quite different. While this article focuses on the political importance of identity it must be kept in mind that differences in the sort of identity can be expected to have important political effects of their own.

18 A growing body of literature has developed arguing that the idea of special deviant subjectivities underlying abnormal conduct is a relatively modern one (see Foucault, 1965, 1977; Weeks, 1977). 
offender. Parole officers dealing with habitual offenders should be highly skilled social workers with knowledge of all the resources in the community for the treatment necessary in each individual case.

In contrast the recent category of high-rate offender partakes of no particular view of the kind of subject, but is based on purely statistical data. ${ }^{19}$ Actuarial techniques can be used to identify people who are more or less likely to be high-rate offenders, but these variables are not integrated into a conception of the underlying subject (Greenwood and Abrahamse 1982). ${ }^{20}$

Both forms of classification are social constructions, but they have different ideological effects. Because they emphasized the existence of an underlying identity, older forms of classification created the possibility of classified subjects resisting the very exercises of power that constituted them. The earlier regimes of classification and control in the penal system and the asylum system greatly increased the power exercised over delinquents and the mentally ill; but they also increased the power invested in the identities of the underlying subjects. The more power was concentrated on these subjects, the more compelling their subjectivity became for political and moral life of society. Eventually this gave rise to social movements on behalf of these subjected populations.

The new actuarial technologies in the penal sphere reverse this process. They are aimed at lessening the investment of power by refining its exercise. The result of their success (which admittedly has not progressed far at present as evidenced by increasingly long prison sentences in most states) might be a welcome lessening of incarceration and of the distance between the convicted criminal and the community. Yet by such a process the penal system will become more invisible, and the criminal subject a less

19 Burgess was one of the first social scientists to urge the adoption of actuarial technologies in criminal justice. He produced statistical tables designed to aid parole authorities in determining which prisoners might be safely released to the community. Yet Burgess's tables compared specific types of offenders such as alcoholics or gamblers. These types (a hallmark of the Chicago School of Sociology) embodied specific identities. The prediction tables utilized by contemporary social scientists such as the Rand Corporation's Peter Greenwood are organized around variables keyed to behavioral or status markers (e.g., arrest before age sixteen, unemployed for two or more years). The high-rate offender is defined through a statistical regression of these variables. While Burgess is a pioneer in the proliferation of actuarial techniques the fully developed form with which this paper is concerned is reached only when the subject is replaced by a field of statistically defined parameters.

20 Recent trends in market research seem to mark a return from the external aspects of people to the internal "values" (Atlas 1984). One highly successful program is Stanford Research Institute's "Values And Lifestyles" (VALS) program. Yet this move "beyond demographics" simply represents a more sophisticated way of targeting segments of the population. VALS's nine "types," such as "survivors," "achievers," or "socially conscious," do not choose groups with any real identity, but offer a way of mapping consumption behavior with more precision than traditional demographics such as income, age, or marital status. 
compelling public figure; in short the exercise of the power to punish will generate less moral and political friction in society (Cohen, 1985).

Another example is provided by the history of homosexuality. The gay liberation movement presumes precisely the idea of a common subjectivity underlying homosexual conduct that was first assumed by the nineteenth century doctors and legislators who classified the homosexual as a type of person to be controlled, disciplined, and normalized (Epstein, 1987). Foucault states (1978: 101):

There is no question that the appearance in nineteenth-century psychiatry, jurisprudence, and literature of a whole series of discourses on the species and subspecies of homosexuality, inversion, pederasty, and "psychic hermaphrodism" made possible a strong advance of social controls into these areas of "perversity"; but it also made possible the formation of a "reverse" discourse: homosexuality began to speak in its own behalf, to demand that its legitimacy or "naturality" be acknowledged, often in the same vocabulary, using the same categories by which it was medically disqualified.

Older forms of exercising power through classification created status groups with a latent but powerful potential for effective political action. Unlike traditional status groups organized around conceptions of honor, delinquents, the mentally ill, and homosexuals were forged around devalued and stigmatized identities. And yet, in the end the existence of an identity, no matter how it is arrived at, may be far more crucial for political empowerment than the particular valence associated with that identity.

The forms of classification associated with actuarial practices are less likely to lead to a dialectic of power/resistance because they create different ideological effects. Earlier classification strategies invested the subjectivity of individuals with significance as a by-product of their very effort to control people. Social meaning went hand in hand with social control. Actuarial classification, with its de-centered subject, seems to eliminate, in advance, the possibility of identity, of critical self-consciousness and of intersubjectivity (cf. Habermas, 1979). Rather than making people up, actuarial practices unmake them.

The examples we have discussed represent narrow segments of society who have been made the subject of both power and knowledge in a greater degree than normal people. Yet it is worth imagining what these examples tell us about the kinds of effect widespread actuarial power might have more broadly on the political and moral life of society. Where power is exercised through actuarial practices there is a decline in the capacity of groups to 
provide identity to members and in the kind of political struggle that identity generates. ${ }^{21}$

We may experience this decline in identity as relaxation of historic social antagonisms. A society composed of status groups lends itself to uncompromising and bitter war, or else highly ritualized forms of alliance. Intercommunal warfare such as that being waged in Beirut or Ulster is generated by the perception that moral disagreement stands behind political dispute and moral survival behind political victory (Mauss, 1966; Weber, 1948b).

In the late nineteenth century scholars were already proclaiming the death of status and birth of class society defined by contractual position rather than ascribed identity. Societies where classes or interest groups predominate downplay the role of moral disagreement in politics. One struggles for power; honor is at best a secondary concern. Hirschman has argued that this diffusion of social tension was seen as a primary virtue of capitalism from the eighteenth century on (1977). But the classes constituted by the disciplinary processes of an industrial society remained potent sources of identity and, of course, of political action.

Today's actuarial practices presage the development of a third model of politics where neither status nor class provides the basis for engagement. Indeed, we have no real models of what aggregate politics look like, but extrapolating from current conditions leads to a disturbing picture. Actuarial practices can mobilize segments of the population and form majorities that have no patterns of shared experience or structures of association and no basis for understanding themselves as motivated by a common cause. The model of aggregated plaintiffs in class action lawsuits discussed above suggests that such majorities would be politically neutered and incapable of projecting a common will. 22

Between the status group on the one hand, and the aggregate on the other one can speak of an attenuation in the moral density of social relations. I call this process de-moralization. I should be clear that by moral I do not mean a system of ethical beliefs. To say that status groups understand themselves morally means that they provide a comprehensive interpretation of what it is to be

21 There is possibly a third and important consequence to the proliferation of actuarial practices: a shallowing of the interiority of the individual subject. The social practices that invest significance in the depths of subjectivity (confession, introspection, examinations, psychoanalysis) have been replaced by practices that invest attention and concern on the external features of lives (standardized testing, new age psychologies like EST, credit checks).

22 An example of this process might be found in the depoliticization of the American working classes since the 1930 s. We tend to attribute this shift to the rise of unions and the general increase in affluence. Yet throughout this period we also find a rapid proliferation of actuarial practices throughout the industrial employment situation: workers compensation, unemployment insurance, social security, pension plans, expansion of consumer credit, etc. 
human; in short they grant an identity. ${ }^{23}$ Classes to the extent that they are defined by external relations of production are already somewhat demoralized in this sense. Yet the possibility of identity (or class-consciousness as it is sometimes called) remains latent. It is possible that members of aggregate formations understand themselves by the formal parameters that make up the aggregate. But if so, this is a self understanding so privative that it can only generate ethical or political beliefs by associating other morally rich conceptions, and these invariably fail to describe the full aggregate. Indeed, intrinsic to the logic of aggregates is a fragmentation of subjects into the numerous formal attributes that could describe them.

It is the moral density of identity that constitutes both the stigma of stereotypes and the empowerment of consciousness raising. To the extent that group differences created by historical processes of domination are demoralized by actuarial representations (as they are for instance in insurance premium setting) it becomes more difficult for disadvantaged groups to generate political power.

Insurance classifications differentiate people in ways that would normally be considered offensive. The ideological power of actuarial practices is their ability to neutralize the moral charge carried by these forms of difference. As a consequence, the political power of these forms of difference to generate identity and thus mobilize constituencies for change is diminished while patterns of domination remain.

Nancy Hartsock has recently argued that post-modernist theories of knowledge pose a threat to the struggle of traditionally oppressed groups (1988). While attacking the totalizing claims of the dominant enlightenment rationality, Hartsock argues that postmodernism has the perverse effect of dismissing the sovereign subject and the political potential of knowledge at precisely the moment when oppressed groups are engaged in struggle for political and epistemological change (1988).

Whatever disempowering effects post-modernist discourses have on the intellectuals who engage in them, the de-centered subject they describe is being materially constructed by the actuarial practices discussed here. Precisely at the point where oppressed groups such as women are ready to begin challenging the construction of their identity by the dominant social forces, power is withdrawing its charge from these contested identities. At a time when feminism is striving to focus social attention on the moral and political implications of gender in society, the actuarial use of gender denies its importance as a moral or political issue. To achieve political change feminism must mobilize women through their

23 This is not unrelated to ethics, for ethical systems presuppose some conception of the good human life. 
identity as women. ${ }^{24}$ But the political charge of identity is dependent on its continuing political and moral relevance in society at large. Rather than reinforcing the perception of gender as a charged distinction in society, the insurance usage casts it as a neutral division.

\section{Antidiscrimination Jurisprudence as a Weapon against the Ideological Effects of Actuarial Practices}

Brilmayer and her co-authors find it disturbing that an insurance-oriented critic like Benston can see little problem in using an actuarial justification for treating women differently in annuity contributions when on the same logic (1983: 228):

... one could deny parole to a black while granting the parole request of a similarly situated white, so long as it could be shown that recidivism correlates with race. College admissions officials could use ethnicity as a factor to predict the grade point averages of applicants, if in fact the two were shown to be correlated.

It is precisely because gender is treated as unproblematic that it is offensive to them. They want to say that, just as race and ethnicity cannot be used to make social allocation choices, even if they are rational, gender is also out of bounds. But to make this argument we must leave behind the focus on individualism and discover the more radical justification for Manhart in the power of antidiscrimination law to resist the de-moralization of difference.

Justice Stevens shares with the rights-oriented defenders of Manhart the view that Title VII is primarily about individuals rather than groups. A scheme such as the one in Manhart, which treats individuals on the basis of a group classification, where that group is one of several types targeted by Title VII, is presumptively invalid. Yet Stevens's antidiscrimination jurisprudence, as laid out in both his statutory and constitutional opinions, suggests that the social construction of group identity plays a significant role in understanding the meaning of the law. Stevens has argued that the law mandates intervention where important distinctions are made between people on the basis of habit. This leads to the view that the law is not merely a shield to protect individuals from group-think, but a sword to alter the way we think about groups.

In Manhart, Stevens argues that group insurance, as the retirement benefit plan at issue, always involves a spreading of loss in the group. "Healthy persons subsidize medical benefits for the

24 Martha Minow has raised important questions concerning the dangers of feminism disregarding differences among women, but this danger is a natural consequence of mobilizing a population for political action. Every effort to reinforce one form of identity is a political act of power that has the effect of reducing the significance of other bonds. When societies stress nationalism, for example, they do so precisely to suppress the outbreak of other forms of class, or ethnic struggle (see M. Minow (1977) "Forward: Justice Engendered" 101 Harvard Law Review 1, 10-95). 
less healthy; unmarried workers subsidize the pensions of married workers; persons who eat,, drink, or smoke to excess may subsidize pension benefits for persons whose habits are more temperate" (Manhart, 435 U.S. at 710).

If gender is viewed as an appropriate basis for halting the loss spreading in favor of a contradictory drive to internalize losses it is "nothing more than habit [that] makes one 'subsidy' seem less fair than the other" (Manhart, at 410, emphasis added, footnote omitted). The habitual construction of difference rather than prejudice per se invokes intervention by antidiscrimination law.

Justice Stevens defined habit more clearly in his dissent to Mathews v. Lucas (427 U.S. 495, 520-521 (1976)):

Habit, rather than analysis, makes it seem acceptable and natural to distinguish between male and female, alien and citizen, legitimate and illegitimate; for too much of our history there was the same inertia in distinguishing between black and white. But that sort of stereotyped reaction may have no rational relationship-other than pure prejudicial discrimination-to the stated purpose for which the classification is being made.

The point is that practices, such as the one in Manhart that treat the gender difference as unproblematic, make it more difficult for the uprooting of habituated gender assumptions to unfold. This, and not hidden prejudice, makes the actuarial use of gender for insurance purposes unacceptable. Antidiscrimination law, in both its Equal Protection and Title VII forms, has the effect of suspending the use of certain differences for social policy purposes. The traditional justifications for this have been individualistic and defensive; we need to protect individuals from stereotyped reactions. The view suggested here is that this suspension has an affirmative and ideological aim. It seeks to maintain the highlycharged character of certain differences in order that a process of political struggle dependent on that charge be able to continue. But for this to make sense we must give up the idea that it is only the individual unfairly trapped in her group circumstances that is the target of antidiscrimination law. The social movement seeking to revolutionize the social circumstances surrounding a certain form of difference is also an important target.

In this analysis, antidiscrimination law is concerned with identity. Identity needs to be protected against two kinds of dangers. First, the value of identity as a means for change is frustrated by the existence of negative stereotypes which so devalue people that they cannot mobilize for change. Second, identity is challenged by practices that treat it as having no underlying character. While we are more used to the first type of challenge, the second may pose the greater problem as explicit forms of racism and sexism give way to silent structural inequalities that diminish the moral and political tension of domination. 
Not too far in the future we may look back at Manhart and see it as a case about actuarial practices. From that vantage it may show up as one point in a growing line of resistance to the use of actuarial techniques in exercising power over people. At present these resistances are diffuse and more or less unconnected. Standardized testing, for example, has come under increasing criticism. Proposals to use actuarial prediction in determining criminal sentences has led to a large outcry. It remains, however, difficult to recognize these resistances as related. In part this is because we have grown up in a society that is constantly testing and comparing us. In part it is because resistance is translated into discourses such as legal rights that deemphasize the methods of power in favor of its purposes.

It is not difficult to see why actuarial classifications would become an important target for feminists. Benefit systems are a vital part of the new property, and thus an obvious concern for those seeking to empower women. ${ }^{25}$ But the fact that these benefit systems are actuarially based is also important for ideological reasons. To be effective as a social movement, feminist politics must seek to mobilize women as a political community. This process is undermined by representations that define women as an aggregation. Just as homosexuals have generated power for resistance from the very social construction of identity that constituted their oppression, women must tap the power of identity invested by the history of their domination by men (Kaplan, 1982).

\section{CONCLUSION}

If I am right, the use of identity to produce political power is becoming more difficult as actuarial practices are becoming more important in our society. Cultural change is slow and subtle. It is hard to describe what is going on without recourse to metaphors. Lacking any imaginable regression coefficient that could prove the effects of actuarial practices, we are left with only the possibility of shared responses to the way these practices operate on us as rituals. In this article I have sought to invoke and explore some of these responses.

As the institutional fabric of society is colonized by actuarial practices it becomes more difficult to invoke political and moral responses in ourselves and others (this is what I have meant by their ideological effect). It is not that we are silenced but increasingly our appeals are lost among what the novelist Don Delillo (1985) called the "white noise" of consumption. As the sense of politically and morally charged differences is diminished, we understand ourselves most strongly in the shifting and listless collec-

25 A number of attacks on benefit plans have made it to the Supreme Court on the issue of gender discrimination, see Geduldig v. Aiello, 417 U.S. 484 (1974), and General Electric Co. v. Gilbert, 429 U.S. 125 (1976). 
tivities of lifestyle and consumption. The long-term result for society is a reduction in the possibility of political change.

The disciplines were used in the nineteenth century to undermine the political potential of the urban "swarms" through technologies of surveillance, isolation, and normalization. Actuarial practices are used today to further diminish the potential for resistance by changing the representations through which we come into ourselves as collective subjects. Rather than concentrating power on particular "dangerous" subjects, actuarial technology changes the social context to make it immune to those subjects (who thus no longer need to be confined and controlled). Barricades are useless against a power that operates in the abstract space of statistical tables.

For most of our history, power has generated resistance by the subjectivities it creates as a by-product in the very people on whom it is exercised. Without any formal suspension of political rights our institutions are becoming more immune from invoking political engagement. Actuarial practices are gradually forming a surface over institutions and social policy arrangements that make them nonconductive of political and moral charge. This means that they do not invoke the sense of political and moral identity in the people that are represented through them.

To recognize this danger we must focus on the ideological effects of the seemingly mundane technical decisions we make concerning how to implement social policies. Social policy is inevitably ideological not only in its substantive goals, but in the techniques through which it is realized; every way of organizing and managing people produces representations of who they are. But to represent does not automatically mean to constitute. The effectiveness of a system of representations is open to contestation. Law remains crucial in any such contest, not simply because it itself is one of the most potent ideological structures in society, but because it contains ideological weapons that might be turned against the representations that disempower us. The decision in City of Los Angeles Department of Water and Power v. Manhart is an example of such resistance.

\section{REFERENCES}

ALTHUSSER, Louis (1971) Lenin and Philosophy. London, New Left Books. ATLAS, James (1984) "Beyond Demographics," The Atlantic (October).

AUSTIN, Regina (1983) "The Insurance Classification Controversy," 131 University of Pennsylvania Law Review 517.

BENSTON, George J. (1982) "The Economics of Gender Discrimination in Employee Fringe Benefits: Manhart Revisited," 49 University of Chicago Law Review 489.

- (1983) "Discrimination and Efficiency in Employee Fringe Benefits: A Clarification of Issues and a Response to Professors Brilmayer, Laycock, and Sullivan," 50 University of Chicago Law Review 250. 
BRIGHAM, John (1987) The Cult of the Court. Philadelphia: Temple University Press.

BRILMAYER, Lea, Richard W. HEKELER, Douglas LAYCOCK, and Teresa SULLIVAN (1980) "Sex Discrimination in Employer Sponsored Insurance Plans: A Legal and Demographic Analysis," 47 University of Chicago Law Review 505.

BRILMAYER, Lea, Douglas LAYCOCK, and Teresa SULLIVAN (1983) "The Efficient Use of Group Averages as Nondiscrimination: A Rejoinder to Professor Benston," 50 University of Chicago Law Review 222.

BRUCE, A., A. HARNO, E. BURGESS, and J. LANDESCO ([1928] 1968) The Workings of the Indeterminate Sentence Law and Parole System in Mlinois. Montclair, NJ: Patterson Smith.

CHEVALIER, Louis ([1958, 1973] 1981) Laboring Classes and Dangerous Classes. Princeton, NJ: Princeton University Press.

COHEN, Stanley (1985) Visions of Social Control: Crime, Punishment, and Classification. New York: Polity Press.

DELLILO, Don (1985) White Noise. New York: Viking Books.

DURKHEIM, Emile (1961) Moral Education. Glencoe, IL: The Free Press.

EPSTEIN, Steven (1987) "Gay Politics, Ethnic Identity: The Limits of Social Constructionism," Socialist Review (May-August) 1987).

EWALD, Francois (1986) L'etat providence. Paris, Grasset.

FOUCAULT, Michel (1965) Madness and Civilization. New York: Random House.

(1977) Discipline and Punish. New York: Pantheon).

(1978) The History of Sexuality Vol. I: An Introduction. New York: Pantheon.

(1985) The Uses of Pleasure. New York: Random House.

FRUG, Gerald E. (1980) "The City as a Legal Concept," 93 Harvard Law Review 105.

GARLAND, David (1985) Punishment and Welfare. Brookfield, VT: Gower.

GRAMSCI, Antonio (1971) The Prison Notebooks, eds. and trans. Quintin Haare and Geoffrey Nowell Smith, New York: International Publishers.

GREENWOOD, Peter, and Alan ABRAHAMSE, (1982) Selective Incapacitation. Santa Monica: Rand.

HABERMAS, Jurgen (1971) Toward a Rational Society. London: Heinemann Books.

- (1979) Communication and the Evolution of Society. Boston: Beacon. (1987) The Theory of Communicative Action, vol. 2 of Lifeworld and System: A Critique of Functionalist Reason. Boston: Beacon Press.

HACKING, Ian (1986) "Making Up People," in T. Heller, M. Sosna, and D. Wellberry (eds.), Reconstructing Individualism. Stanford: Stanford University Press.

HARTSOCK, Nancy (1988) "Rethinking Modernism: Minority v. Majority Theories," 7 Cultural Critique 187.

HEIDEGGER, Martin (1962) Being and Time. New York: Harper and Row.

HIRSCHMAN, Albert O. (1977) The Passions and the Interests. Princeton, NJ: Princeton University Press.

KAPLAN, Temma (1982) "Female Consciousness and Collective Action: The Case of Barcelona 1910-1918," in N. Keohane, R. Rosaldo, and R. Gelpi (eds.), Feminist Theory: A Critique of Ideology. Chicago: University of Chicago Press.

KENNEDY, Duncan (1976) "Form and Substance in Private Law Adjudication," 89 Harvard Law Review 1685.

KIMBALL, Spencer L. (1979) "Reverse Sex Discrimination: Manhart," 1979 American Bar Foundation Research Journal 83.

(1980) "Reprise on Manhart," 1980 American Bar Foundation Research Journal 915.

LAYCOCK, Douglas, and Teresa A. SULLIVAN (1981) "Sex Discrimination as 'Actuarial Equality': A Rejoinder to Kimball," 1981 American Bar Foundation Research Journal 221.

MARX, Karl (1970) Capital, Vol. I: London: Lawrence and Wishart.

MAUSS, Marcel (1954) The Gift: Forms and Functions of Exchange in Archaic Societies, trans. Ian Cunnison. Glencoe: Free Press. 
MEEHL, Paul E. (1954) Clinical Versus Statistical Prediction. Minneapolis: University of Minnesota Press.

MINOW, Martha (1987) "Forward: Justice Engendered," 101 Harvard Law Reviero 9.

NIETZSCHE, Frederick (1967) On the Genealogy of Morals. New York: Vintage Books.

RHODE, Deborah L. (1982) "Class Conflicts in Class Actions," 34 Stanford Law Review 1183.

ROTHMAN, David (1971) The Discovery of the Asylum. Boston: Little, Brown.

RUTHERGLEN, George (1979) "Sexual Equality in Fringe Benefit Plans," 65 Virginia Law Review 199.

SIMON, Jonathan (1987) "The Emergence of a Risk Society: Law Insurance and the State," Socialist Review (Sept.-Oct.) 1987).

UNGER, Roberto M. (1975) Knowledge and Politics. New York: The Free Press.

WEBER, Max (1948a) "The Meaning of Discipline," in H. Gerth and C. Mills (eds.), From Max Weber. London: Routledge, Kegan, Paul.

(1948b) "Politics as a Vocation," in H. Gerth and C. Mills (eds.), From Max Weber. London: Routledge, Kegan, Paul. (1968) Economy and Society. New York: Bedminister Press.

WEEKS, Jeffrey (1977) Coming Out: Homosexual Politics in Britain from the 19th Century. London: Quartet Books.

WORTHAM, Leah (1985) "Insurance Classification: Too Important to be Left to Actuaries," 19 University of Michigan Journal of Law Reform and Legislation 349.

\section{CASES CITED}

City of Los Angeles Department of Water and Power v. Manhart, 435 U.S. 702 (1978).

Griggs v. Duke Power Co., 401 U.S. 424 (1971).

Connecticut v. Teal, 457 U.S. 440, 458-459 (1982).

United Steel Workers v. Weber, 443 U.S. 193 (1979).

Mathews v. Lucas, 427 U.S. 495 (1976).

Brown v. Board of Education, 347 U.S. 483 (1954).

Geduldig v. Aiello, 417 U.S. 484 (1974).

General Electric Co. v. Gilbert, 429 U.S. 125 (1976). 